\title{
HOME-BIAS-IN-CONSUMPTION BASED ON DIFFERENT BRAND PREFERENCES IN THE EAST AND THE WEST OF GERMANY
}

\author{
Bahles, $M$.
}

In international macroeconomics, there is a specific concept explaining deviations in international trade relations showing that countries have a bias and a strong preference for the consumption of their home-country goods. This article presents an application of the concept on brand preferences in West and East Germany, where a home-bias-inconsumption has been observed for the East of Germany. It is the first application of the concept on the territory of brand preference that explains the strong rootedness of the Eastern German consumers to their regionally known and familiar brands. The goal of the article is to elaborate more deeply the differences in attitudes towards brands between Eastern and Western German consumers. The main research method is secondary analysis of the data collected in two large research studies: (1) "West-East brand study", and (2) "Consumer Analysis". The results of the presented study have interesting managerial implications in brand management, showing that brands should utilize their local rootedness.

JEL classification: M31

Keywords: Home-bias-in-consumption; local brand preference; brand heritage and nostalgia.

\section{Introduction}

The famous article of Maurice Obstfeld and Kenneth Rogoff "The Six Major Puzzles in International Macroeconomics: Is There a Common Cause?" (Obstfeld and Rogoff, 2000) deals with different puzzles for the explanation of international economic relations.

One of the puzzles is the "home-bias puzzle" showing that countries have a bias and strong preference for the consumption of their home-country goods. They discuss the reasons for this economic phenomenon as it can be caused by additional costs based on tariffs, non-tariff barriers and exchange rate risks, as well as possible higher transportation costs. Also within the EU, there is a high preference for home products observed due to consumer preferences (Balta and Delgado, 2009). This article intends to show another cause for the home bias in consumption: The impact of local brand preference shown by an evident preference of Eastern German consumers towards the product brands of the former German Democratic Republic (GDR).
The article wants to show that even though it's nearly 25 years after the political change and reunification of West and East Germany, the consumers in the Eastern part of Germany still have a stronger preference and affinity towards their known and familiar product brands from the times of the former GDR.

The complexity of attitudes towards brands is a mixture of rational and emotional factors that, in the case of brands with a longer history, cannot be understood and explained without the concept of brand heritage. Brand heritage is the intangible value of the brand, which has been built over the many years of the brand's presence in the market. Brand heritage is usually a set of associations connected to the brand, which has its roots in the history of a brand. These associations are linked or better to say represent the core value of the brand to the consumer. This phenomenon together with the nostalgia effect is one of the reasons why consumers from the East part of Germany still tend to buy local brands (Machková, Král and Lhotáková, 2010). Right after the political 
reunification of West and East Germany, consumers were excited and preferred West German products and brands (Veenis, 2011). In recent years, the preferences have changed and East German consumers tend to buy the older East German brands, namely because of so-called “(N)Ostalgie" (Berdahl 1999). But in order to prove if this development is still true, valid data has thus far been missing.

\section{Methodology}

The main research method is secondary analysis. Two prestigious studies were used as a source of valid and reliable information.

(1) The paper will refer to a study that has been conducted yearly since 2010: The "West- East brand study" (West-Ost-Markenstudie) of the MDR (Mitteldeutscher Rundfunk), the East German broad- casting station of Saxony, and Saxony-Anhalt and Thuringia.

Description of the research methodology of the "West-East brand study":

West- East brand study 2010

The study in 2010 is the first survey of the annually conducted "West-East brand study". It is based on a qualitative preliminary study with one-on-one interviews in November 2009, followed by a quanti-tative survey with 1,500 telephone interviews (CATI)from January to March 2010. The nationwide repre-sentative sample consists of individuals aged 14 to 75 years.

West- East brand study 2011

For the West-East brand study 2011, the basis is a qualitative preliminary study in 2010, and a telephone survey (CATI) in the period April to July 2011. For this survey 2,000 people were interviewed nationwide. The representative sample consists of individuals aged 14 to 75 years.
For both surveys, the conducting institute is IMK Institute for Marketing and Communication Research $\mathrm{GmbH}$, Erfurt.

(2) Due to the fact that there is only limited access to the study in 2012 and 2013, the author of the article will prove the different preferences in buying certain product brands using the data provided by the public survey of the "Consumer Analysis" (VerbraucherAnalyse) released by the Axel Springer AG and the Bauer Media Group for certain product segments. The "Consumer Analysis" is a regular survey about the consumption of products in various categories among the German population. It is a representative study with more than 30,000 respondents, conducted annually since 1982 .

Description of the research methodology of the "Consumer Analysis":

Basic population: German-speaking population above 14 years, in private households, in the Federal Republic of Germany (70,213 million). Sample and survey: 32,218 cases collected from October 2010 to March 2012 by the institutes Enigma, Ipsos, Ifak, Marplan.

\section{Differences in the product brand preferences between Eastern and Western Germany}

After 2010, 2011, 2012 also the most recent "West- East brand study 2013" indicates a strong preference of the consumers in the so-called "New federal states" (Neue Bundesländer) for the product brands from East Germany as they have known them from the years of the former GDR. Examples are the local Cola drink "Vita Cola", the skin care brand "Florena", the sweets brand "Halloren", the laundry detergent brand "Spee" or beer brands like "Hasseröder", Köstritzer" and "Wernesgrüner" among others.

\section{Image 1 Product brands of East Germany}

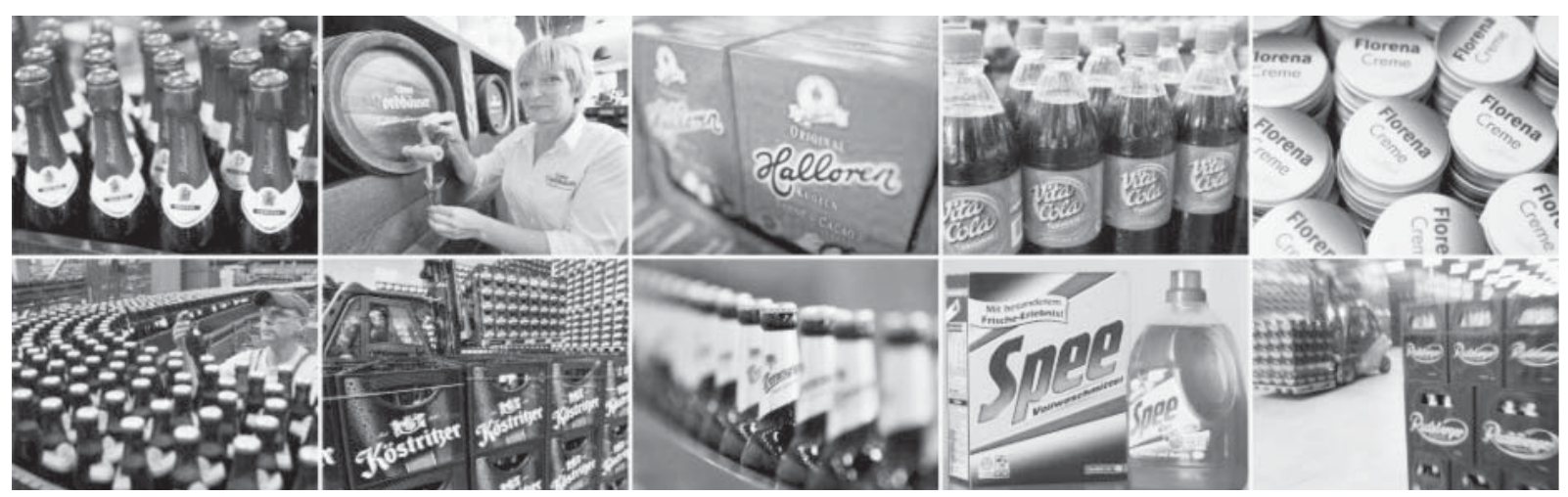

Source: n-tv.de 
Figure 1 Attractiveness of East brands (in \%)

Source: West- East brand study 2010 $(n=1.500)$

Figure 2 Image of East brands compared to West brands (in \%)

Source: West- East brand study 2010 $(n=1.500)$
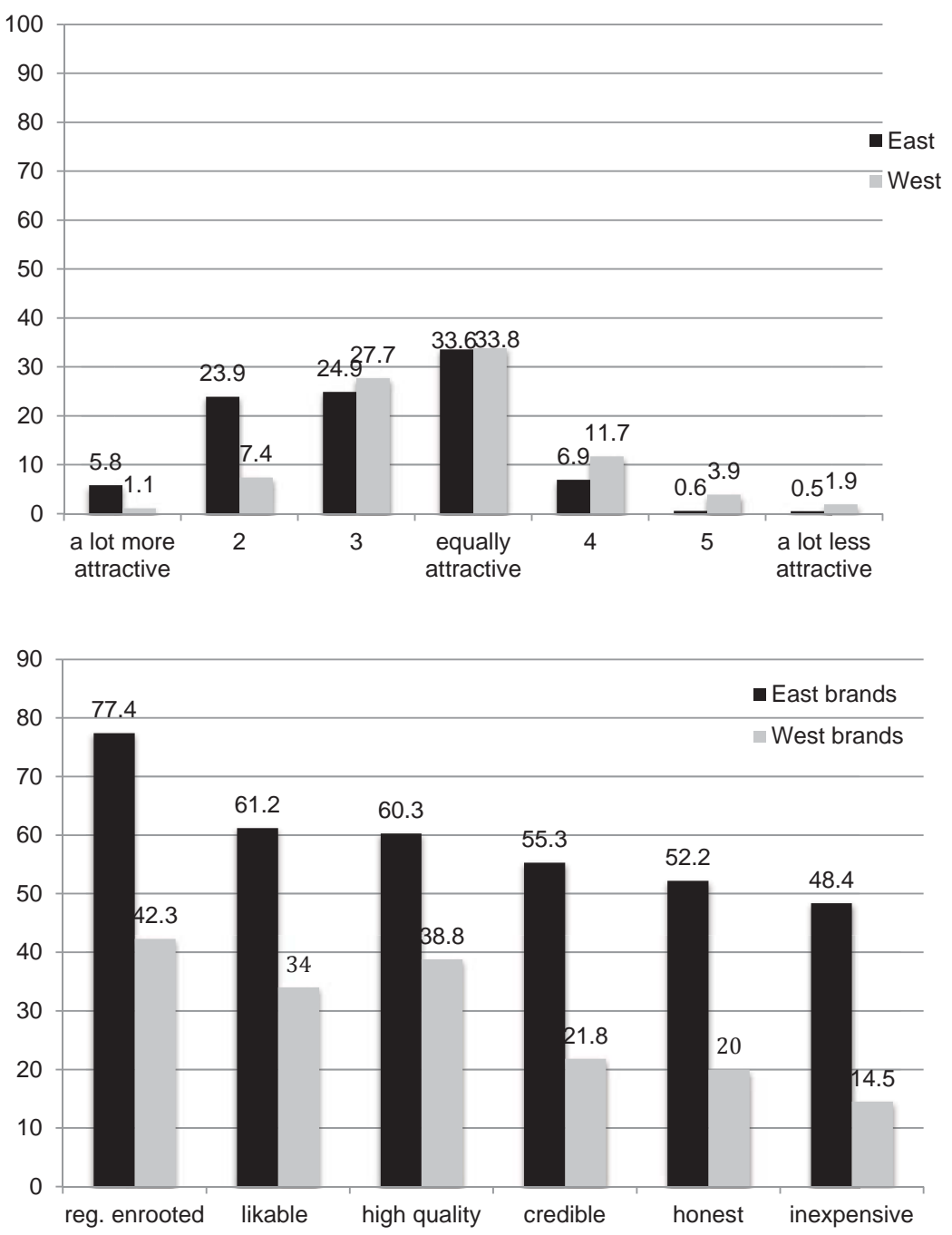

Already in 2010, in the first "West- East brand study", more than $50 \%$ of the respondents of East Germany declared that product brands from the East are more attractive to them compared to product brands from the West (see figure 1).

The strengths of the product brands from the East are seen in their attributes, that they are more strongly regionally enrooted $(77.4 \%)$, likable $(61.2 \%)$, of high quality $(60.3 \%)$, more credible $(55.3 \%)$, honest $(52.2 \%)$ and less expensive (48.4\%) (see figure 2).

It is interesting to see that lower price is apparently not the most significant attribute of the product brands from the East. The strongest characteristic is the regional rootedness that shows strong local ties of the consumers in East Germany as a possible explanation for their preference to East German product brands.
Also, the results from the survey in 2011 show a clear preference towards the product brands from the East with $34.2 \%$ of the consumers in East Germany. On the other hand, consumers of West Germany do not have a certain preference for the product brands from West Germany - only $9.2 \%$ (see figure 3 ).

In addition, more than $40 \%$ of the consumers from the East of Germany consider the "origin of the product brand" as important for the brand preference, compared to only $4.4 \%$ from the West (see figure 4 ).

Evidently, there is still a big preference of the consumers in the East of Germany for their local brands, which they have known from the times of the former GDR. On the other hand, there are indicators that this is particularly true for the consumers older than 40 years. Overall, the preference is lower with younger consumers in the East of Germany. 

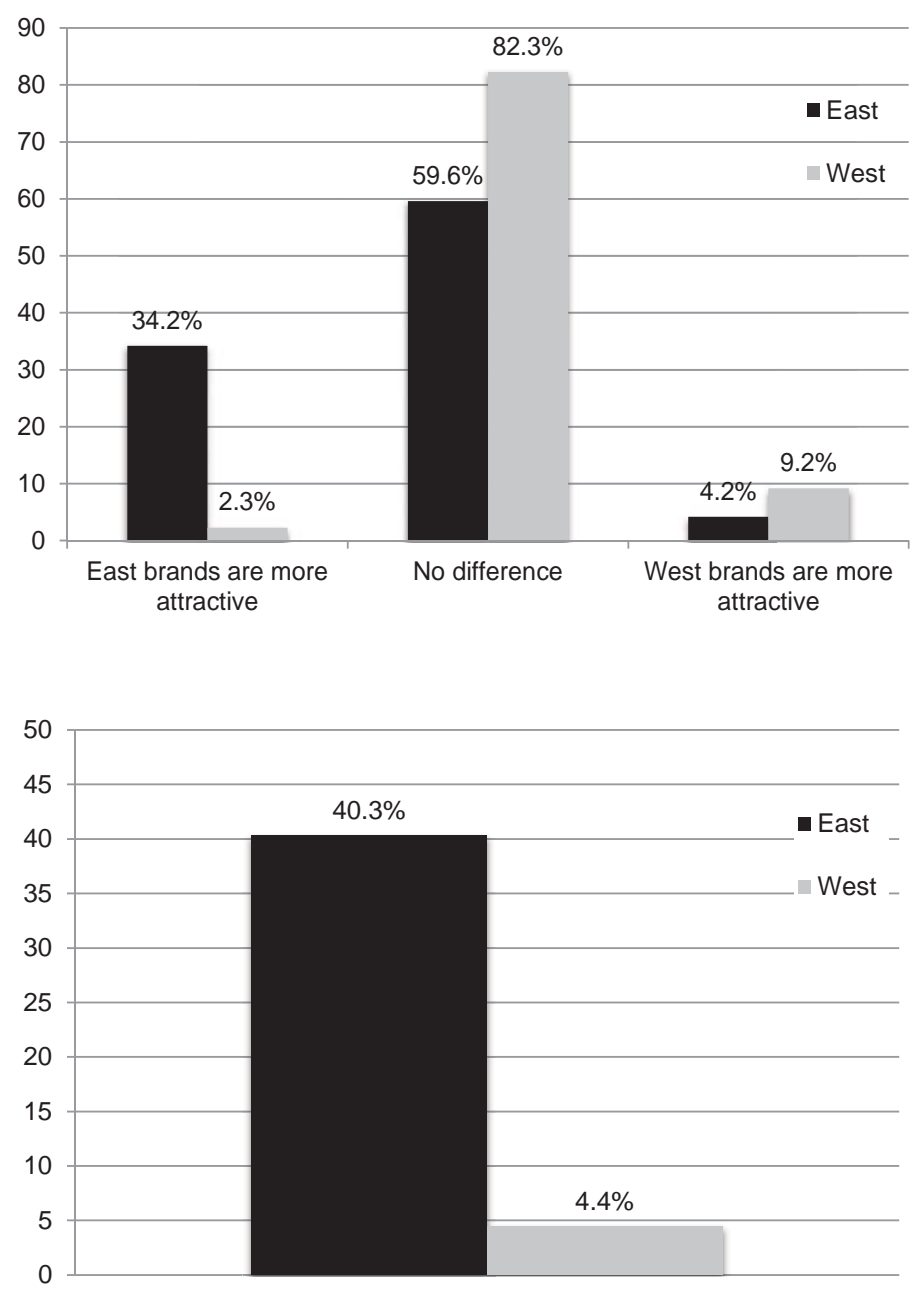

Figure 3 Brand attractiveness East / West

Source: West- East brand study $2011(n=2.000)$

Figure 4 Preference for brands from the home region

Source: West- East brand study $2011(n=2.000)$
But there are also indicators in the study of 2013 that the "East brands" are becoming more and more known and popular in Western Germany as well, due to the fact that they are considered as "traditional", "iconic", "likable" and "honest" (von Haken, 2013). It is stated that product brands from the East which survived their struggling years right after the political changes, have become attractive for consumers in the West now.

Brands like Halloren sweets, Spee laundry detergent, Florena and the beer brands Radeberger as well as Köstritzer are known and popular in West Germany. But that is the case only for a few of the East German brands and some of them are owned by Western German companies, such as Spee by Henkel, Radeberger by the Oetker group and Florena by Beiersdorf which also produces Nivea. Check with current data of the "Consumer Analysis" The data of the most recent survey from 2012 about the consumption in certain product categories (for which data is compiled) shows a clear preference of the consumers in Eastern Germany towards product brands from East Germany.

Table 1 Consumption index of East brands vs. West brands in Eastern Germany

\begin{tabular}{|l|c|l|c|}
\hline East brand & $\begin{array}{c}\text { Consumption } \\
\text { index }\end{array}$ & West brand & $\begin{array}{c}\text { Consumption } \\
\text { index }\end{array}$ \\
\hline Vita-Cola & 412 & Coca-Cola & 72 \\
\hline Hasseröder & 344 & Beck's & 89 \\
\hline Rotkäppchen & 250 & Deinhard & 82 \\
\hline Spreequell & 284 & Apollinaris & 76 \\
\hline Halloren & 330 & Ferrero & 94 \\
\hline Spee & 250 & Persil & 97 \\
\hline Florena & 310 & Nivea & 116 \\
\hline
\end{tabular}

Source: Consumer Analysis $2012(n=32.218)$ 
For example, there is a strong preference for the Vita Cola with a consumption index of 412 . That means there is a significant over proportional consumption of Vita Cola in East Germany compared to Coca-Cola with an index of only 72 (based on the overall consumption in the German population - index $=100$ ).

Similar is the preference for Hasseröder, an East German beer brand, with an index of 344 compared to Beck's with an index in East Germany of only 89, or the consumption of Rotkäppchen, the East German sparkling wine brand, compared to Deinhard the Western German brand (250 vs. 82). The same is found for Spreequell, an East German mineral water brand, with an index of 284 compared to the traditional Western mineral water brand Apollinaris with an index of only 76 in the consumption in East Germany. A strong consumption index in the East is also stated for the sweet brand Halloren with 330 in East Germany and an average index of Ferrero with 94. Similar are the consumption indices for the detergent brand Spee with a strong index of 250 but also an average consumption index of 97 for the Western brand Persil. It means that the consumption of these Western brands achieved average consumption in East Germany. This is also the case for the skin care brands Florena and Nivea. Though there is a strong preference towards Florena (index of 310 ) there is also a quite strong index of Nivea (116). That means that the consumption of this skin care brand, formerly only available in the West of Germany, has also become popular among consumers in the East of Germany.

\section{Conclusion}

As the data shows, there is (still) home-bias-in-consumption in the East of Germany because of a strong preference of the consumers for East German product brands. The reason for this is, above all, the strong rootedness of Eastern German consumers to their regionally known and familiar brands: A feeling of nostalgia that increases brand preferences (Orth and Gal, 2012; Kessous and Roux, 2010).

But there are indications that, in the future, the home bias and the difference in brand preference could become less because of demographic change (rather the older consumers in the East prefer East brands) but also because some East product brands have become similarly popular for the consumers in the West of Germany. The reasons for this phenomenon are seen in the values the brands stand for, like tradition, credibility, likability as well as authenticity and originality. These values create an emotional bond of the consumers with the brands, which is important in brand management in order to create brand preference.

The upcoming surveys in the "West-East brand study" will show if the differences in the product brand preference and the consumption patterns of the East and West in Germany will become less in the future.

\section{Managerial implications and brand recommendation}

\section{For the East German product brands:}

The East German product brands have to become more attractive as well for the younger consumers in East Germany. For this, they should communicate their product value and difference besides the fact that they are from the East.

In addition, they should increase their awareness in the Western part of Germany on order to become relevant and sustainable in the whole country. As the recent data shows, the East brands can be attractive for West German consumer by communicating the values they stand for. Values like tradition, authenticity and honesty are more and more relevant for consumers in West Germany (Mackat, 2007).

For the long-term, they should not stand for "East brands" in particular anymore. They should stand for regionally rooted, traditional brands that offer good product quality and representing relevant and attractive brand values (like credibility, honesty and originality).

\section{For the West German product brands:}

In order to increase brand preference in the Eastern part of Germany, West German product brands should address the consumers in East Germany more specifically, so that they achieve a higher emotional bond and connection with the East German consumers.

Only "to be from the West" is not a relevant or convincing argument anymore. It is more important to communicate an actual and reasonable argument for the brand to the people in the East (Mackat, 2007).

Through these adjustments in brand positioning and brand communication all the product brands - from the East and from the West - can become relevant in both parts of Germany and could be attractive nationwide. The preference for product brands could be more similar in both parts and the distinction between so-called "East brands" and "West brands" could become lower in the future. 


\section{References}

Balta, N., Delgado, J. (2009). Home Bias and Market Integration in the EU. CESifo Economic Studies, 55(1): $110-144$.

Berdahl, D. (1999). (N)Ostalgie for the present: Memory, Longing, and East German Things. Ethnos, 64(2): 192-211.

Machková, H., Král, P., Lhotáková, M. (2010). International Marketing. Prague: Oeconomica.

Mackat, A. (2007). Das deutsch-deutsche Geheimnis: Mit der Werteentwicklung in Ost und West zum gesamtdeutschen Markenerfolg. Berlin: Superillu Verlag.

Obstfeld, M., Rogoff, K. (2001). The Six Major Puzzles in International Macroeconomics: Is There a Common Cause?, Volume 15. Boston: NBER/Macroeconomics Annual (MIT Press).

Orth, U., Gal, S. (2011). Nostalgic brands as mood boosters. Journal of Brand Management, 19: 666-679.

Kessous, A., Roux, E. (2010). Brands Considered as "Nostalgic": Consequences on Attitudes and Consumerbrand Relationships. Recherche et Applications en Marketing, 25(3): 29-55.

Veenis, M. (2011), Cola in the German Democratic Republic. East German Fantasies on Western Consumption. Oxford University Press.

Von Haken, N. (2013), West-Ost-Markenstudie 2013: Die Unterschiede verfestigen sich. (accessed February 2014), [available at http://www.mdr-werbung.de/wom2013_in_ leipzig0. html].

West- East brand study 2010 (2010). MDR Advertising $\mathrm{GmbH}, \mathrm{IMK}$ - Institute for Marketing and
Communication Research GmbH. (accessed February 2014), [available at http://www. mdr -werbung.de/ fileadmin/media/mdrw/pdf/WOM HANDOUT_Internet_ VL_100930.pdf].

West- East brand study 2011 (2011). MDR Advertising $\mathrm{GmbH}, \mathrm{IMK}$ - Institute for Marketing and Communication Research GmbH. (accessed February 2014), [available at http://www.mdr-werbung.de/ fileadmin/media/mdrw/pdf/WOM2011_Handout_ VL_111010.pdf].

West- East brand study 2013 (2013). MDR Advertising $\mathrm{GmbH}, \mathrm{IMK}$ - Institute for Marketing and Communication Research GmbH. (accessed February 2014), [available at http://www.mdr-werbung.de/ wom2013_in_leipzig0.html].

Consumer Analysis 2012 (2013). Axel Springer AG, Bauer Media Group. (accessed February 2014), [available at http://www.verbraucheranalyse.de].

n-tv (2013). Beim Einkaufen ist der Osten patriotisch, (accessed February 2014), [available: at http://www.n-tv.de/wirtschaft/ Rotkaeppchen-Halloren-Radeberger-Ost-Marken-imWesten-immer-beliebter-article11561281.html].

\section{Author}

Diplom-Kaufmann Michael Bahles

Assistant Professor

Department of International Trade

Faculty of International Relations

University of Economics, Prague

Nám. W. Churchilla 4, 13067 Prague 3,

Czech Republic

michaelbahles@hotmail.com 